\title{
Prevalence of Retrocaecal Appendix among Patients with Appendicitis in a Tertiary Care Hospital of Nepal
}

Sanzida Khatun, 'Dipendra Thakur, ${ }^{2}$ Diwakar Kumar Shah'

'Department of Anatomy, Nobel Medical College, Biratnagar, Nepal, ${ }^{2}$ Department of General Surgery, Nobel Medical College, Biratnagar, Nepal.

\section{ABSTRACT}

Introduction: Appendicitis is one of the most common causes of acute abdomen. The clinical presentation of appendicitis and its susceptibility to acute inflammation may be affected by the length and position of vermiform appendix. Length and position of appendix are variable. The aim of the study was to find the prevalence of retrocaecal appendix among patients undergoing appendectomy for appendicitis.

Methods: A descriptive cross-sectional study was performed in 264 patients undergoing appendectomy in Department of Surgery, Nobel Medical College, Biratnagar, Nepal from $1^{\text {st }}$ May, 2018 to $15^{\text {th }}$ May, 2019. Ethical approval was taken. Simple random sampling was done. The position of appendix was noted before appendectomy. Subgroup analysis was done on the basis of gender and length of appendix recorded in centimeters with a measuring scale immediately after removal of appendix. Data was collected in excel and was analyzed in SPSS version 16.

Results: Prevalence of retrocaecal appendix among patients with appendicitis was 95 (35.98\%). Similarly, other positions noted were pelvic in 67 (25.37\%), post-ileal in 61 (23.10\%), pre-ileal in 11 $(4.16 \%)$ and subcaecal in 30 (11.36\%) individuals. The length of appendix ranged from $1.7 \mathrm{~cm}$ to 14.7 $\mathrm{cm}$. The mean length was $8.67 \pm 2.44 \mathrm{~cm}$.

Conclusions: The most common position of appendix in patients with appendicitis is retrocaecal position followed by pelvic position in both males and females.

Keywords: appendicitis; appendix; positions of appendix; vermiform appendix.

\section{INTRODUCTION}

The vermiform appendix, a long, narrow tube like structure, arises $2 \mathrm{~cm}$ below the ileocaecal opening from the posteromedial wall of caecum. ${ }^{1}$ Its length and position are variable. The length ranges from 1 to $25 \mathrm{~cm} .^{2}$ The five most common positions of appendix include pelvic, retrocaecal, subcaecal, pre-ileal and post-ileal positions. ${ }^{1}$

Appendicitis is one of the most common causes of acute abdomen. ${ }^{3}$ The clinical presentation of appendicitis and its susceptibility to acute inflammation may be affected by the length and position of appendix. ${ }^{4,5}$ However, some studies show that position does not alter the clinical presentation. ${ }^{6,7}$ Although few studies have been done in appendicitis in Nepalese population, the length and position of inflamed appendix have not been reported in Nepal.

The aim of the study was to find the prevalence of retrocecal appendix among patients with appendicitis undergoing appendectomy in a tertiary care hospital of Nepal.

Correspondence: Dr. Sanzida Khatun, Department of Anatomy, Nobel Medical College, Biratnagar, Nepal. Email: ksanzida12@gmail. com, Phone: +977-9860342335. 


\section{METHODS}

A descriptive cross-sectional study was performed in patients undergoing appendectomy in Department of Surgery, Nobel Medical College, Biratnagar, Nepal. The study was conducted from $1^{\text {st }}$ May, 2018 to $15^{\text {th }}$ May, 2019.

The ethical approval was received from Institutional Review Committee of Nobel Medical College. Individuals who had undergone abdominal surgery previously were excluded from the study. A written informed consent was obtained from the subjects or the guardians of the pediatric patients.

Sample size was calculated using the following formula,

$\mathrm{n}=\mathrm{Z}^{2} \times(\mathrm{p} \times \mathrm{q}) / \mathrm{d}^{2}$

where,

$$
\begin{aligned}
& n=\text { sample size } \\
& p=\text { prevalence, } 45 \% \text { (educated guess) } \\
& q=1-p \\
& d=\text { margin of error, } 6 \% \\
& Z=1.96 \text { at } 95 \% \mathrm{Cl}
\end{aligned}
$$

Based on the above formula, the minimum sample size at $95 \%$ confidence interval with $6 \%$ error was calculated to be 264 and thus study was conducted in 264 patients. Simple random sampling was done.

The position of appendix was noted before appendectomy and the length of appendix was recorded in centimeters $(\mathrm{cm})$ with a measuring scale immediately after removal of appendix. The data were collected and analyzed using Excel and Statistical Package for Social Sciences 16 software respectively. Subgroup analysis was done on the basis of age, gender and length of appendix.

\section{RESULTS}

Prevalence of retrocaecal appendix was 95 (35.98\%). Similarly, other positions noted were pelvic in 67 (25.37\%) patients, post-ileal in 61 (23.10\%) patients, pre-ileal in $11(4.16 \%)$ patients and subcaecal in 30 $(11.36 \%)$ patients. The most common position of appendix was retrocaecal position followed by pelvic, post-ileal, subcaecal and pre-ileal positions (Table 1).

The study was performed in 264 patients where 168 $(63.6 \%)$ were males and $96(36.4 \%)$ were females. The mean age of the study population was 28.6 years.
The length of appendix ranged from $1.7 \mathrm{~cm}$ to $14.7 \mathrm{~cm}$. The mean length was $8.67 \pm 2.44 \mathrm{~cm}$. The mean length of appendix was $8.74 \pm 2.41$ $\mathrm{cm}$ in males and $8.55 \pm 2.48 \mathrm{~cm}$ in females.

\begin{tabular}{|lccc|}
\hline \multicolumn{3}{|c|}{$\begin{array}{l}\text { Table 1. Frequency of different positions of appendix } \\
\text { in both sexes. }\end{array}$} \\
\hline $\begin{array}{l}\text { Position of } \\
\text { Appendix }\end{array}$ & Male & Female & Total \\
Pelvic & $43(25.6 \%)$ & $24(25.0 \%)$ & $67(25.4 \%)$ \\
Retrocaecal & $61(36.3 \%)$ & $34(35.4 \%)$ & $95(36.0 \%)$ \\
Subcaecal & $20(11.9 \%)$ & $10(10.4 \%)$ & $30(11.4 \%)$ \\
Pre-ileal & $6(3.6 \%)$ & $5(5.2 \%)$ & $11(4.2 \%)$ \\
Post-ileal & $38(22.6 \%)$ & $23(24.0 \%)$ & $61(23.1 \%)$ \\
Total & 168 & 96 & 264 \\
& $(100.0 \%)$ & $(100.0 \%)$ & $(100.0 \%)$ \\
\hline
\end{tabular}

The most common position was retrocaecal in both sexes (Figure 1).

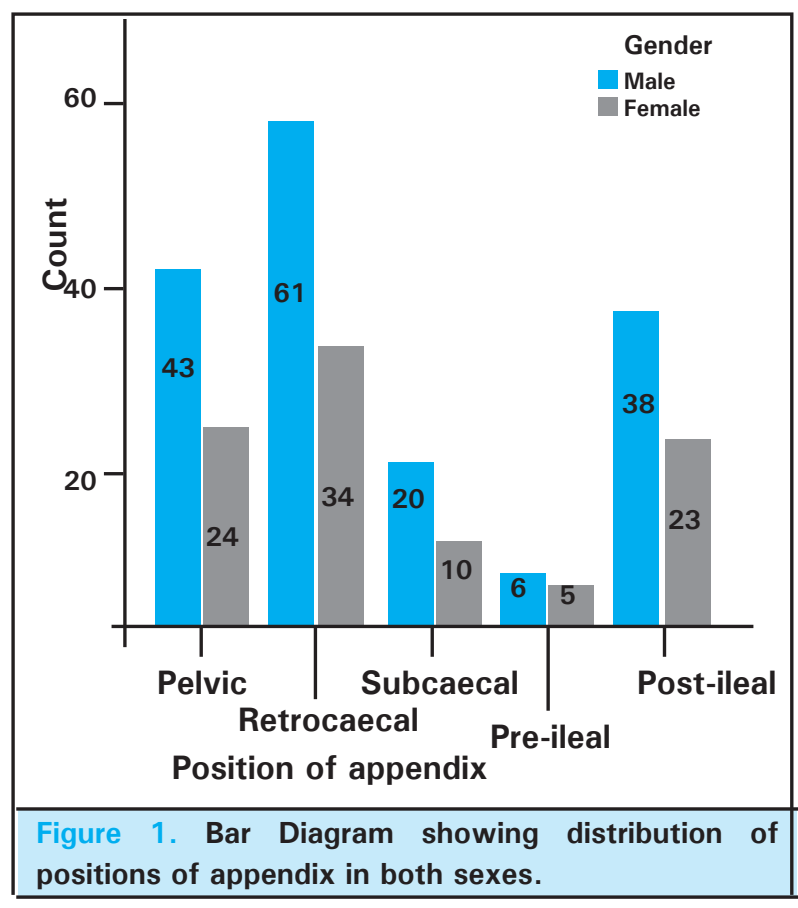

\section{DISCUSSION}

The length and position of the vermiform appendix are inconsistent in humans. It is an organ which is mobile and can change its position in various situations. ${ }^{8}$ This study has demonstrated that most commonly found position of appendix in subjects with appendicitis is retrocaecal followed by pelvic then, post-ileal, paracolic and least prevalent is pre-ileal. In consistence to our finding, the findings of Clegg-Lamptey, ${ }^{9}$ Paul, ${ }^{10}$ 
Khatun et al. Prevalence of Retrocaecal Appendix among Patients with Appendicitis in a Tertiary Care Hospital of Nepal

Wakeley, ${ }^{11}$ Mwachaka ${ }^{12}$ and Setty ${ }^{13}$ reveal that retrocaecal is the most common position of appendix followed by pelvic position.

In contrast to the finding of this study, the findings of Ghorbani, ${ }^{14}$ Rahman, ${ }^{15}$ Ahmed, ${ }^{16}$ Tofighi $^{17}$ and Golalipour ${ }^{18}$ show that the most common position of appendix is pelvic position. The pelvic position of appendix favors pressure free surrounding and in retrocaecal position, the appendix is kinked by loaded caecum or ascending colon. ${ }^{19}$ Ghorbani illustrates in his study that $75 \%$ of appendix are anterior to caecum which favors early diagnosis and short hospitalization. ${ }^{14}$

Searle described in his study that appendix achieves adult proportion after 3 years of age and does not continue to grow throughout childhood. ${ }^{20}$ The current study estimated $8.67 \pm 2.44 \mathrm{~cm}$ mean length of the appendix. There is significant association between length of appendix and different age groups. The mean length of appendix is $8.74 \pm 2.41 \mathrm{~cm}$ in males and $8.55 \pm 2.48 \mathrm{~cm}$ in females. The mean lengths of appendix in male and female was $9.12 \mathrm{~cm}$ and 8.03 $\mathrm{cm}$, respectively in a study performed in Iran. ${ }^{14}$ In a cadaveric study in Kenya, the mean length of appendix estimated was $7.65 \pm 2.36 \mathrm{~cm} .{ }^{12}$ The mean length of appendix was lower, $6.52 \mathrm{~cm}$ in males and $6.28 \mathrm{~cm}$ in females, in a study performed in India. In the same study, the mean length in fetus was found to be 2.0 to $5.0 \mathrm{~cm} .{ }^{13}$ In a post mortem study done in 4,680 subjects, it was found that the length of $61 \%$ of appendices ranged from $6.00-9.00 \mathrm{~cm} .{ }^{21}$ An appendix, $28 \mathrm{~cm}$ long, in retrocaecal position was reported in adult female cadaver in India. ${ }^{22}$

It has been hypothesized from previous studies that appendix lying anterior to caecum or in pelvic position prevents kinking and favors early diagnosis of appendicitis, whereas, retrocaecal position may produce kinking thus compromising the blood supply to appendix. ${ }^{14,19} \mathrm{~A}$ larger sample of appendicitis subjects will help establish whether retrocaecal or pelvic positions support or prevent appendicitis. Further researches are yet to be done to understand the relation between particular position of appendix and occurrence of appendicitis.

\section{CONCLUSIONS}

The most common position of appendix in patients with appendicitis is retrocaecal position followed by pelvic position in both males and females.

\section{ACKNOWLEDGEMENTS}

We acknowledge Department of General Surgery, Nobel Medical College, Biratnagar, Nepal for their support.

Conflict of Interest: None.

\section{REFERENCES}

1. Standring S. Gray's Anatomy. $41^{\text {st }}$ ed. [place unknown]: Elsevier; 2015. 1142 p. [Full Text]

2. Schumpelick V, Dreuw B, Ophoff K, Prescher A. Appendix and caecum. Embryology, anatomy and surgical applications. Surg Clin North Am. 2000 Feb;80(1):195-318. [PubMed | Full Text]

3. Anderson JE, Bickler SW, Clhang DC, Talamini MA. Examining a common disease with unknown etiology: trends in epidemiology and surgical management of appendicitis in California, 1995-2009. World J Surg. 2012 Dec;36(12):2787-94. [PubMed | Full Text]

4. Hardin JD. Acute appendicitis: review and update. Am Fam physician. 1999 Nov;60(7):2027-34. [PubMed | Full Text]

5. Varshney S, Johnson CD, Rangnekar GV. The retrocaecal appendix appears to be less prone to infection. Br J Surg. 1996 Feb;83(2):223-4. [Full Text |DOI]

6. Shen GK, Wong R, Daller J, Melcer S, Tsen A, Awtrey S, Rappaport W. Does the Retrocecal Position of the Vermiform Appendix Alter the Clinical Course of Acute Appendicitis? A Prospective Analysis. Arch Surg. 1991 May;126(5):569-70. [PubMed |Full Text]
7. Grunditz T, Ryden CI, Janzon L. Does the retrocecal position influence the course of acute appendicitis. Acta Chir Scand. 1983;149(7):707-10. [PubMed]

8. Nayak BS. Why the tip of vermiform appendix has variable position? Med hypotheses. 2010 Dec;75(6):682-3. [uuMed | Full Text]

9. Clegg-Lamptey JN, Armah H, Naaeder SB, Adu-Aryee NA. Position and susceptibility to inflammation of vermiform appendix in Accra, Ghana. East Afr Med J. 2006;83(12):670-8. [PubMed | Full Text]

10. Paul UK, Naushaba H, Begum T, Alamq MJ, Alim AJ, Akther J. Position of vermiform appendix: a postmortem study. Bangladesh J Anat. 2009;7(1):34-6. [Full Text]

11. Wakeley CP. The position of the vermiform appendix as ascertained by an analysis of 10,000 cases. J Anat. 1933 Jan;67(Pt 2):277-83. [ [PubMed | Full Text]

12. Mwachaka P, El-busaidy H, Sinkeet S, Ogeng'o J. Variations in the position and length of the vermiform appendix in a black kenyan population. ISRN Anat. 2014 Apr 30;2014.

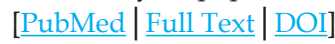


13. Setty SN, Katikireddi RS. Morphometric study of human cadaveric caecum and vermiform appendix. Int J Health Sci Res. 2013;3(10):48-55. [Full Text]

14. Ghorbani A, Forouzesh M, Kazemifar AM. Variation in anatomical position of vermiform appendix among iranian population: an old issue which has not lost its importance. Anat Res Int. 2014;2014:313575. [PubMed |Full Text |DOI]

15. Rahman MM, Khalil M, Rahman H, Mannan S, Sultana SZ, Ahmed S. Anatomical positions of vermiform appendix in Bangladeshi people. J Bangladesh Soc Physiologist. 2006;1:5-9. [Full Text]

16. Ahmed I, Asgeirsson KS, Beckingham IJ, Lobo DN. The position of the vermiform appendix at laparoscopy. Surg Radiol Anat. 2007 Mar 1;29(2):165-8. [PubMed |Full Text]

17. Tofighi H, Taghadosi-Nejad F, Abbaspour A, Behnoush B, Salimi A, Dabiran S, et al. The anatomical position of appendix in Iranian cadavers. Int J med Toxicology Forensic Med. 2013 Dec 2;3(4):126-30. [Full Text]
18. Golalipour MJ, Arya B, Azarhoosh R, Jahanshahi M. Anatomical variations of vermiform appendix in south-east Caspian sea (Gorgan-Iran). J Anat Soc India. 2003;52(2):141-3. [Full Text]

19. Schwartz S I, Brunicardi FC, Andersen DK, Billiar TR, Dunn DL, Hunter JG, Matthews JB, Pollock RE. Schwartz's Principles of Surgery. United States of America:McGraw-Hill Education $10^{\text {th }}$ ed; 2015. 1241-58 p. [Full Text]

20. Searle AR, Ismail KA, MacGregor D, Hutson JM. Changes in the length and diameter of the normal appendix throughout childhood. J Ped Surg. 2013 Jul 1;48(7):1535-9. [Full $\underline{\text { Text }}$ DOI]

21. Collins DC. The length and position of the vermiform appendix: a study of 4,680 specimens. Annals Surg. 1932 Dec;96(6):1044-8. [릴ed | Full Text $\mid \underline{\text { DOI] }}$

22. Boddeti RK, Kulkarni R, Murudkar PK. Unique $28 \mathrm{~cm}$ long vermiform appendix. Int J Anat Res. 2013;1(2):111-4. [Full Text] 